\title{
MOOCs, learning designers and the unbundling of educator roles in higher education
}

Steven White

Arts University Bournemouth

Su White

University of Southampton

Kate Borthwick

University of Southampton

In university educational technology projects, collaborations with external partners pose a range of opportunities and challenges. Educational projects are often associated with unbundling of conventional higher education roles though there is limited empirical work in this area. This is particularly the case with massive open online courses (MOOCs), where further research is needed into the production of courses and the roles of those who produce them. This study investigated the extent to which conventional roles of academics are unbundled during MOOC production partnerships between universities and an external MOOC platform provider. The findings indicate that aspects of conventional educator roles are substantially unbundled to learning designers and other seemingly peripheral actors. Unbundling is partially driven by pragmatic decisions shaping course production processes which need to accommodate the massive and open properties of MOOCs, the nature of cooperation agreements with external platform providers and the reputational risk associated with such public ventures. This study adds to empirical knowledge on the unbundling of roles in online learning projects, and the findings have relevance for those involved in decisionmaking, planning and development of such projects in higher education.

Implications for practice or policy:

- Managers of online learning projects could use these insights to inform recruitment or training of learning designers (e.g., instructional designers, educational designers).

- Managers of online learning projects could use these insights to inform planning and decision making for projects involving external partners and collaborations.

- Learning designers could use these insights to help plan for online learning projects which involve open content, massive numbers of participants, high-profile collaborations.

Keywords: unbundling, learning designer, massive open online course, MOOC, multi-site case study

\section{Introduction}

Educational technology projects in higher education (HE) often require extensive collaboration, and this inevitably poses serious challenges for established institutional structures and the roles of those involved. One such challenge is the unbundling of conventional roles, especially those of academics who have historically fulfilled a "jack-of-all-trades" (Moore, 2007, p. 113) function, covering various aspects of conventional course development and delivery. Unbundling in this study is defined as the division of academic work into specialist functions and activities (Paulson, 2002, p. 125), and was studied in the context of massive open online course (MOOC) development projects.

Unbundling of roles in MOOCs is of particular interest, as high-profile media accounts of these courses have depicted them as a "tsunami" or "avalanche" (Bulfin et al., 2014, p. 296) of disruption in global HE. The fact that MOOCs are often produced in collaboration with quasi-commercial platform providers adds complexity to collaborations and affects the motivations and narratives which accompany the initiatives (Weller, 2015). However, even more measured accounts of MOOCs in HE have recognised that they do not fully fit within commonplace understandings of university functions of teaching, research and service. Using Littlejohn's (2013) definition of MOOCs as “course[s] aiming at large-scale interactive participation 
and open access via the internet" (p. 2), this research explored the roles of those involved in the development of these courses in HE in the United Kingdom (UK).

Online course development requires contributions from and collaboration between a range of individuals (Caplan \& Graham, 2008). To distinguish the participants in the study from the wider academic staff, those academics involved directly in MOOC development are named educators. The online learning specialists are referred to as learning designers. Though a range of terms are used for related roles in this area (learning technologist, instructional designer, educational designer), learning designer is used here to reflect an emphasis on social constructivist learning theory in Web-based environments (Kenny et al., 2005).

This paper builds on previous work on the unbundling of educator roles in online learning (Tucker \& Neely, 2010) and responds to calls for more research into MOOC development roles (Liyanagunawardena et al., 2013; Veletsianos \& Shepherdson, 2016). Reporting on the unbundling element of a wider research project into MOOC development (see also White, 2019; White et al., 2020), it investigated the extent to which educator roles are unbundled in MOOC development initiatives, using a multiple case study of three UK universities. The universities involved are public institutions for whom the educators and learning designers in the study work. These universities have formed partnerships with the same quasi-commercial platform provider.

Drawing on Boyer's (1990) four-part characterisation of scholarship (as discovery, integration, application and teaching), the research used interview and documentary data as a way to understand whether participation in MOOC development impacts educator roles. In this paper, we first examine current understandings of the nature of educator and learning designer roles in MOOCs and online learning more widely. After outlining the multi-site case study method, we describe the findings on changing roles in course design, provision of course content and course development processes. The study concludes that the case study institutions share novel concerns with reputational enhancement and reputational risk which accompany high-profile, open and massive courses. Such concerns shape MOOC development initiatives, and lead to an unbundling of conventional educator course development roles, making learning designers increasingly central in shaping and coordinating MOOC projects.

\section{Literature review}

\section{Unbundling of roles in HE}

Despite a recent focus on links between educational technology and changing roles and practices in universities, the concept of the unbundling of roles in HE is not new. Indeed, Gehrke and Kezar noted that unbundling of HE services, responsibilities and roles has occurred for "several centuries" (2015, p. 97). However, they also argued that limited empirical research exists on this phenomenon. In terms of online learning, Tucker and Neely (2010) explored how in the United States of America, educators have become subject matter experts in development of conventional online courses, whilst instructional designers focus on aligning curriculum with technology and materials. Focussing on the UK context, Macfarlane (2011) commented on how e-learning coordinators or learning technologists take on para-academic positions as academic roles are unbundled to them.

Unbundling in this area represents a relatively recent change. Previously, course development was part of a "cottage industry" (Elton, 1996, p. 138) where academics worked independently as a "jack-of-all-trades" (Moore, 2007, p. 113) on the teaching, research and service aspects of their work to a great extent. In their historical review of unbundling in universities, Gehrke and Kezar (2015) found that unbundling processes are often a response to pressures external to universities or new ideas in education. As an example of this, online learning initiatives are frequently initiated or influenced by external factors such as the massification of HE (Selwyn, 2017), something certainly relevant to MOOC initiatives in UK universities.

\section{Educator and learning designer roles in MOOCs}

However, as noted above, research into those who produce MOOCs is lacking, especially qualitative studies (Veletsianos \& Shepherdson, 2016). Previous studies have divided MOOCs into broad pedagogical categories of many-to-many connectivist cMOOCs and one-to-many instructor-led xMOOCs (Rodriguez, 2013). Though this oversimplifies the range of courses that have subsequently developed, the fundamental 
distinction is sufficient for this research, which focussed on courses which tend towards the xMOOC type. Existing studies of such courses have considered educator perspectives on MOOC development but lack detailed attention to learning designer roles (Blackmon, 2018; Lowenthal et al., 2018;; Zheng et al., 2016). However, a preliminary report into this research project has highlighted learning designers as significant in understanding MOOC development (White \& White, 2016). Najafi et al. (2015) considered both educator and learning designers in finding that MOOCs are a team effort, but the unbundling of roles was not a focus of this single institution case study. Interestingly, Zheng et al. found that to fully understand MOOC production, a "hotlistic view" (Zheng et al., 2016, p. 216) is needed. They cited an educator's view that "teaching a MOOC is more like resourcing and implementing a large project", but struggled to explain the "invisible systems and actors" which they sensed underpin these projects (2016, p. 216). White et al. (2020) confirmed empirically the existence of these tacit roles and systems, arguing that new (sociotechnical) spaces and roles are shaped during MOOC development, but the study lacks direct consideration of unbundling processes.

The high-profile nature of these massive open courses and the attendant sense of reputational risk which accompanies development has been acknowledged as significant for MOOC development in the literature (León-Urritia et al., 2018; White et al., 2020). However, possible links between reputational risk for institutions and platform providers and the unbundling of roles have yet to be explored. A related consequence of creating massive open courses is their impact on legal issues such as copyright of course materials. Cheverie (2013) and Literat (2015) have provided reviews and commentary, but Czerniewicz et al. (2016) considered this empirically and, significantly, identified tensions between openness and copyright in MOOC production and delivery in their study of a single MOOC. The findings of Czerniewicz et al. (2016), White et al. (2020), and Zheng et al. (2016) suggest that educators and learning designers face substantial challenges in producing MOOCs, but limited research exists on the relationship between the two roles. Looking at the literature on conventional online course development may further inform this understanding.

\section{Course development roles in conventional online education}

The need for collaboration between a variety of individuals and functions in conventional (non-MOOC) online learning is well established, and the importance of learning designers within such collaborations is clear (Caplan \& Graham, 2008). However, existing research has focussed on the "broker" (Keppell, 2007, p. 68) or "bridging" (Cowie \& Nichols, 2010, p. 77) roles of learning designers (or those in related positions). Such roles somehow operate simultaneously at the margins of institutional activity and the centre of academic projects (Oliver, 2002). This role has been described as both "pivotal" and "peripatetic" (Beetham et al., 2001, p. 4), yet learning designers' roles in MOOCs have yet to be considered from this perspective. Further, the reliance on video in online courses and the substantial workload it requires (Gregory \& Lodge, 2015) suggest an impact on collaborative roles, and MOOCs certainly share this emphasis on video content.

Though not directly referencing unbundling or MOOCs, Whitchurch's (2013) work on a "third space" in $\mathrm{HE}$ is also relevant. Third space activities in $\mathrm{HE}$ span or disregard traditional distinctions between academic and professional roles, and Whitchurch has highlighted online learning as a relevant area of third space activity. Indeed, Bisset (2018) has commented on the "collaborative expertise" (p. 16) and "strategic agency" (p. 16) of "educational designers" (p. 1) in Australian university educational technology projects, but again without reference to MOOCs.

It seems, therefore, that MOOC development is likely a site of the unbundling of roles in HE, especially in terms of educator and learning designer roles, but is underexplored in this respect. This study addresses this gap, focussing specifically on educator and learning designers working for public universities in collaboration with a quasi-commercial platform provider.

\section{Methods}

This study responded to Veletsianos and Shepherdson's (2016) call for more in-depth, qualitative studies of MOOCs and sits within the interpretivist paradigm. Using a multi-site case study approach, it attempted to generate a nuanced understanding of the complex educational contexts in which MOOCs are produced (Creswell, 2014; Kirkwood \& Price, 2014). This approach is useful in research which seeks to understand 
the "messy realities" of educational technology projects as "socially grounded" phenomena (Selwyn, 2010, p. 70). The approach is instrumental and theory-led (Simons, 2009, p. 21) in using concepts of unbundling and Boyer's (1990) categories of scholarship as a perspective through which to explore the cases.

The study attempted to answer the following research question: To what extent are educator roles unbundled in MOOC development projects?

We identified potential sites for the case studies through an initial desk study of UK MOOC initiatives and interviews with authorities in the field of UK online learning. From the limited group of UK MOOCproducing universities, we identified a purposive sample. We selected three universities from this sample, which balanced features for comparison and commonalities to create a suitable "quintain" (Stake, 2013, p. 23) or set for multiple case analysis. Universities A, B and C were of different sizes and used different approaches to MOOC development between 2016 and 2018, yet shared a common platform provider and coverage of subject areas in courses selected for study.

In terms of data collection, we conducted 34 semi-structured interviews alongside document analysis between 2016 and 2018. This approach combined rich qualitative data with a degree of "methodological and data triangulation" (Bowen, 2009, p. 29). The participants, identified via snowball sampling as core to MOOC development processes, were educators, learning designers and management or other professionals such as legal or marketing roles, selected as valuable sources of information (Suri, 2011, p. 69) about course development. Table 1 shows the scope and type of data collection and the numbers of participants in each MOOC-related development role.

Table 1

Data collection methods and samples at the case sites

\begin{tabular}{lccccc}
\hline $\begin{array}{l}\text { Research } \\
\text { site }\end{array}$ & $\begin{array}{c}\text { Documents } \\
\text { analysed }\end{array}$ & Interviews & \multicolumn{3}{c}{ Participant role } \\
\cline { 4 - 6 } & & & Educator & $\begin{array}{c}\text { Learning } \\
\text { designer }\end{array}$ & $\begin{array}{c}\text { Management or } \\
\text { legal professional }\end{array}$ \\
\hline University A & $10(25$ pp. $)$ & 10 & 7 & 2 & 1 \\
University B & $14(47$ pp.) & 14 & 6 & 5 & 3 \\
University C & $15(23$ pp.) & 10 & 6 & 2 & 2 \\
\hline Total & $39(95$ pp.) & 34 & 19 & 9 & 6 \\
\hline
\end{tabular}

We interpreted the data using thematic analysis as a way to analyse and produce in-depth accounts of complex data (Braun \& Clarke, 2006). Thematic analysis is frequently used to establish understandings of events in a particular context, but uses a "factist" perspective that "assumes data to be more less accurate and truthful indexes of the reality "out there"' (Sandelowski, 2010, p.79). To counter-balance possible inaccuracies or biases in the data, as researchers, we maintained a reflexive position and used both interview data and document analysis to corroborate accounts and interpretations of the research context.

Data analysis and interpretation combined application of an existing framework (see Boyer's 1990 categories of scholarship below) with adaptation and progressive focussing of these "organizing concepts" (Stake, 2008, p. vi). This is in line with Stake's (2013) recommendations on conducting multi-site case studies. Boyer's work provides a substantial foundation of empirical work on which to build an analysis of the unbundling of educator roles. Though originating in the United States of America, Boyer's (1990) work provides a way to recognise the scope of academic work, resisting a traditional emphasis on research. Boyer sought to go beyond the narrow view of scholarship as research, teaching and service, which fails to encompass the breadth of academic work and the interrelationships between the constituent elements of it. From extensive interviews with academics, Boyer produced a four-part categorisation of scholarship as discovery, application, integration and teaching, and elaborated subcategories of activity under each heading (Boyer, 1990; adapted to table form by Nibert, 2001, p. 27) as outlined in Table 2 below.

As Table 2 shows, Boyer's (1990) categories divide academic activities into production of new knowledge via research (discovery), interpretation and synthesis of information (integration), sharing or use of knowledge to benefit wider society (application), and the systematic study of teaching and learning processes in ways that can be shared and developed by others (teaching). 
Table 2

Boyer's (1990) elements of scholarship (adapted to table form by Nibert, 2001, p. 27)

\begin{tabular}{|c|c|c|}
\hline Type of scholarship & Purpose & Measures of performance \\
\hline Discovery & $\begin{array}{l}\text { Build new knowledge } \\
\text { through traditional research }\end{array}$ & $\begin{array}{l}\text { - } \quad \text { Publishing in peer-reviewed forums } \\
\text { - } \quad \text { Producing and/or performing creative } \\
\text { - } \quad \text { Crork within established field } \\
\text { - }\end{array}$ \\
\hline Integration & $\begin{array}{l}\text { Interpret the use of } \\
\text { knowledge across disciplines }\end{array}$ & $\begin{array}{l}\text { Preparing a comprehensive literature } \\
\text { review } \\
\text { - Writing a textbook for use in multiple } \\
\text { disciplines } \\
\text { - Collaborating with colleagues to design } \\
\text { and deliver a course }\end{array}$ \\
\hline Application & $\begin{array}{l}\text { Aid society and professions } \\
\text { in addressing problems }\end{array}$ & $\begin{array}{l}\text { - } \\
\text { corving industry or government as a } \\
\text { - } \quad \text { Assuming leadership roles in } \\
\text { professional organisations } \\
\text { - } \quad \text { Advising student leaders, thereby } \\
\text { fostering their professional growth }\end{array}$ \\
\hline Teaching & $\begin{array}{l}\text { Study teaching models and } \\
\text { practices to achieve optimal } \\
\text { learning }\end{array}$ & $\begin{array}{l}\text { - Advancing learning theory through } \\
\text { classroom research } \\
\text { - Developing and testing instructional } \\
\text { materials } \\
\text { - Mentoring graduate students } \\
\text { Designing and implementing a program- } \\
\text { level assessment system }\end{array}$ \\
\hline
\end{tabular}

Though influential and widely cited (Boyer et al., 2015), this approach has been criticised for being difficult to apply in practice, with the interaction between the four elements often being ignored (Boshier, 2009). However, careful application of the framework can still be useful as a "basis for understanding changes in scholarly practices", including in the area of digital scholarship (Weller, 2011, p. 43) and of learning technology in particular (Bennett \& Oliver, 2011). We therefore analysed educator roles in MOOCs in this study thematically. We used Boyer's (1990) categories as a way to interpret the interview and documentary data and so examine how involvement in MOOC development affects educator scholarly activities.

We informed all participants of the nature of the study and the treatment, storage and disposal of their data. All participants provided informed consent. The study received full ethical approval from our host institutions and further approvals from ethics gatekeepers at each of the participant institutions.

\section{Findings}

In this section, quotes from research participants are given in abbreviated form to represent their university (UA, UB, UC) and role (LD - learning designer, ED - educator, MGMT - management, LEG - legal). For example, UA-ED-01 represents the first of seven educators interviewed at University A. Some positions straddle these roles; thus, they include two elements (e.g., UA-ED/MGMT-01 represents an individual involved as both an educator and manager in MOOC development).

\section{The context of MOOC production: reputational enhancement and risk}

As with any online course, the context in which these MOOCs are produced is important in understanding the development process. Analysis of interview and documentary data revealed some significant incentives and pressures underlying MOOC development, and roles of those involved in it. 
Participants across the case sites and roles felt that MOOC development initiatives were primarily aimed at enhancing the university brands, acting as showcases for the institutions. Analysis of course planning documents supported these ideas. Other motivations were identified, including a desire to innovate in education, fulfil an outreach function or change the digital culture of the institutions. However, there was far less consensus on these other motivations or evidence to support them in course documentation. The massive and open nature of the courses seems directly linked to this underlying concern with branding and image. Massiveness and openness afforded universities and educators significant exposure both directly through the courses themselves, and in media coverage of what was at the time a relatively new type of educational offering.

However, this potential for exposure also created pressures on those involved in course development. Indeed, considerable reputational risk existed alongside the possibility of reputational enhancement for individuals and their host institutions. MOOC collaborations with an external, quasi-commercial partner also created novel challenges and tensions relating to compliance with legal, marketing and commercial requirements. Both the universities involved and the platform provider with which they collaborated imposed a range of restrictions with which educators were unaccustomed in more conventional teaching and course design activities.

\section{Unbundling and intertwining Boyer's (1990) teaching and integration activities: course design, content and development processes}

The incentives and pressures associated with MOOC development had implications for the roles of learning designers and educators. Participant accounts contain statements relevant to each of Boyer's (1990) categorisations of scholarship (discovery, application, integration and teaching). However, thematic analysis of educator accounts combined with document analysis reveals limited evidence of substantive activity in terms of the discovery and application aspects of educator roles. In common with media narratives of the time (see Bulfin et al., 2014), participants frequently speculated on the potential impact of participation in MOOC development for their wider research (discovery), collaboration (integration), teaching and public engagement (application) activities, but we found little evidence of such impact.

In fact, the main finding of this study is that rather than an expansion of educator roles, MOOC development entailed a narrowing and unbundling of educator roles on these projects. Particular "lead" educators (UBLD-01; UC-LD-02) were clearly identified and associated with courses. However, significant responsibility and "final say" (UB-LD-01) over course design, content and development processes and decisions shifted from educators to learning designers during the projects. This entails a significant unbundling of conventional educator roles which occurred as part of MOOC development, specifically occurring in Boyer's (1990) scholarly functions of teaching and integration activity.

The particular elements of Boyer's (1990) teaching and integration activities found to be most relevant to MOOC development were:

- development and testing of instructional materials (teaching) and

- collaborating with colleagues to design/deliver a course (integration).

As discussed in the Literature review section, MOOCs presented relatively novel challenges for universities. Consequently, learning designers filled an organisational gap in taking on these teaching and integration activities, which became closely intertwined in practice. As a result, the Findings section does not separate teaching and integration functions into discrete categories of activity.

Instead, educator and learning designer roles are examined in terms of course design, course content, and course development processes. Looking in depth at these subjects in turn will help demonstrate how the teaching and integration elements of educator roles are unbundled and intertwined in MOOC development projects.

\section{Learning designers at the centre of MOOC development}

It is crucial to note that across the case sites and roles, learning designers were regarded as central in MOOC development activity. Indeed, they were variously described as the "fulcrum" (UA-ED-07), "linchpin" 
(UB-ED-05) and the "centre of things" (UC-ED-01) in a role which "just touches on everything" (UA-LD02). Management and legal stakeholders also shared this view - placing learning designers at the centre of their understandings of MOOC development (UA-ED/MGMT-01; UB-LEG-01; UC-MGMT-02). Educators were also clear that creating MOOCs was substantively different than their experience of other forms of course development in HE (both online and face-to-face). Educators at each location conceded that learning designers "very much managed the projects", in contrast to "other courses [in which] you are both creator and deliverer" of the materials (UA-ED-08). The centrality of learning designers in MOOC projects evolved over time at each site, but had implications for course design, course content and course development processes.

\section{Unbundling educator control of course design}

Daniel commented in 2014 that MOOCs do not neatly fit with established university structures and functions; and this proved to be the case in this study. The massive and open elements of MOOCs were attractive for their potential for branding and showcasing institutions, but these elements challenged conventional course design practices. In partnering with a quasi-commercial platform provider, the universities (and individual educators especially) relinquished some control over the learning design of their courses. Open courses aimed at attracting large numbers of participants had to take into account learners with vastly differing levels of subject knowledge, motivation, educational experience and language competence amongst many other factors. This meant that the course platform design (and guidance from the platform provider) favoured short, high-production-value videos; relatively lightweight reading materials with associated high-quality images or diagrams; and the use of related discussion questions (for peer discussions on platform forums, with occasional interventions or comments from teaching assistants or educators themselves). Other activity types were used, but the video and/or short text plus discussion activities formed the common basis of the learning design.

This design was unfamiliar to educators more used to the flexibility of face-to-face teaching or collaborating on conventional online course design and it caused tension and challenges in the early stages of course development. As a result, educators across cases reported a "tedious process" (UA-ED-06) of back and forth negotiation over the course design between educators, learning designers and the platform provider. Educators at University B described course design as a "frustrating" (UB-ED-02) and "really long, drawnout process" (UB-ED-03). The approach at University C was distinct to some extent, giving educators more choice in course design and ensuring "ownership [of courses] resides with the academic team" (UC-LD01). However, learning designers still provided extensive training and guidelines and admitted that they maintained a relatively "tight grip" on design choices (UC-MGMT-02). Such activity represented an unbundling of both the teaching and integration elements of Boyer's educator roles. Conventional educator understandings of course development and design collaboration were challenged from the outset.

Though educators often worked with learning designers to agree the overall structure and sequencing of input and activities, their subsequent contributions of course materials were often very limited or heavily edited after submission. Indeed, this meant that some educators "were not involved in the course build at all" (UA-LD-01) beyond provision of simple text content. At University B, for example, learning designers reported having "a very free hand" (UB-LD-01) in design decisions beyond initially agreed frameworks. As the following section will show, these limitations were imposed as a result of both production deadlines and institutional and platform provider quality standards. Such limitations amounted to a substantial unbundling of educator roles in producing content.

\section{Shaping and editing academically lightweight course content}

The fact that these quasi-commercial, high-profile, brand-focussed courses were open to all and potentially massive in scale had important implications for the type and presentation of course content. All videos, sound, images and texts used in MOOCs had to adhere to copyright standards distinct from the defined audience educational contexts of conventional university courses. In addition, the institutions and platform providers had standards for branding and presentation of materials, which were also quite different to those of educators creating courses for internal university use.

Educator roles in generating or selecting content for MOOCs were rapidly unbundled as the requirements of MOOCs became better understood. Educators were frequently required to produce original texts as 
subject matter for courses in an academically lightweight form suitable for a heterogeneous audience. It quickly became clear that conventional academic styles of communication did not fit the requirements of this new type of course. Feedback from learning designers and platform providers highlighted the fact that educators produced "just too much material" (UC-ED-03) or that the texts were "too heavy, too academic" (UB-ED-05).

Similar comments were received on educator contributions to course videos. Contributions often failed to meet video producer requirements in that they were "too technical or too specific" (UC-ED-04) and "too dense, too text heavy" (UC-ED-05). This was problematic as videos produced during "the filming [were seen as] kind of central" to the structure and content of courses (UA-LD-02). Furthermore, the high-profile nature of the courses created a pressure for high-production-value videos, and thus a level of technical expertise in video production and time commitment, which educators could not provide.

These novel demands resulted in an unbundling of educator control of course content. Learning designers reported across the case sites that they would review, edit and at times rewrite content on a regular basis (UA-LD-01; UA-LD-02; UB-LD-01; UB-LD-03; UC-LD-01; UC-LD-03). Indeed, videos and texts were subject to extensive "editing" (UC-LD-03), at times learning designers feeling they had to "edit [educator contributions] pretty hard" or even remove them if they did not meet production standards (UC-LD-01). Educators did report changing their approach to contributions as they realised the style should be "somewhere in the middle between engagement with the public and rigorous academic study" (UC-ED01), but learning designers maintained an editorial role throughout.

Even the selection of illustrative images for courses involved a renegotiation of power relations in collaborative activities (Boyer's 1990 integration function) and an unbundling of Boyer's development of instructional material role for educators on courses. Copyright restrictions extended to use of images on MOOCs, and this led to interaction and sometimes conflicts between educators and institutional authorities on copyright.

Indeed, early-stage development saw tensions and conflict between university legal or marketing departments and educators, including at times "continual fighting" (UB-LD-01) over text, video or imagebased elements of courses. Tensions arose as legal or marketing departments focussed on the use of images which promoted university brands or safeguarded legal positions on copyright, whilst educators advocated free use of materials which foregrounded the academic integrity and accuracy of courses. Learning designers often found themselves mediating between sometimes "entrenched" positions as parties were "arguing the toss" over materials which "didn't meet the university brand, [or] didn't meet the [platform] brand" (UB-LD-01). Ultimately, all case sites adopted "strict" (UC-LD-02) policies on copyright and the checking of course content. At University B, this resulted in educator criticisms of a constraining "no risk" approach taken by the legal department. Certainly, an unbundling of educator decision-making is clearly evidenced where legal "have to go through [and approve] every asset" used on a course (UB-LEG-01).

As the Findings sections show, the involvement of actors other than educators and learning designers was an important driver of the unbundling process, with learning designers taking on central positions in MOOC development, mediating between these disparate interests, unbundling the collaborative and materials development elements of educator roles substantially. The following section outlines the distinctive course development processes which resulted.

\section{Learning designer control of course development processes}

In managing the competing demands which MOOCs brought to universities, novel course development processes and procedures were developed. The unbundling of educator roles in this area has already been identified as educators commonly felt that learning designers "very much managed the projects", and this learning designer influence extended to processes of course progress checking and review. Indeed, even at University $\mathrm{C}$, where educators were given perhaps most freedom to create courses, learning designers "really led the internal review process" (UC-LD-03) and maintained a "pretty tight grip on course development" (UC-MGMT-02). Educators across the cases felt this lack of control was distinct from conventional production and review processes and represented an unbundling of their role of "creator" and "deliverer" of courses. 
As the extensive involvement of legal departments suggests, the unbundling of educator roles was one way of mitigating against the reputational risk that producing high-profile MOOCs might represent. Indeed, analysis of documents at University B and University $\mathrm{C}$ that formalised the rationale and procedures for course development revealed an emphasis on managing the reputations of the individuals and universities involved. These documents often focussed on concerns with control of copyright or branding, to the extent that learning designers commented "copyright is a huge part of what we do" (UA-LD-01). At University $\mathrm{B}$, the legal perspective was central in development processes to the extent that "we don't have one [an oversight meeting] without legal" (UB-LD-03). Although University C again gave educators more freedom to choose materials in this respect, this choice resulted in copyright experts working closely with educators to find "openly licensed content" (UC-LEG-01) and spending substantial time in reviewing and checking acceptability of such content.

MOOC development processes included a substantial focus on managing complexity, resources and risk within relatively tight timeframes. This pressurised context created a tendency for learning designers to make somewhat conservative choices in course design, materials selection and development processes. Unbundling of educator responsibility and control in development processes resulted, with one learning designer realising that development decisions "are going to have to go through me" (UB-LD-01). Going further, the same individual reflected that the complexity of course development resulted in a "design decision ... [of] placing a constraint on myself as well ... and that was a significant ... design influence I suppose" (UB-LD-01). This sense of "strict" (UC-LD-02) control over course development was reported by learning designers across the case sites.

Unbundling also manifested as diminished educator control of course development processes in terms of their access to course development resources and to the processes of course oversight. Educators at University A, for example, typically found their access to content, tools and technologies "narrowly constricted" (UA-ED/MGMT-01) by development procedures. For example, educators had no access to the MOOC platform at all, so were distanced from the physical building of the course. At University B, learning designers made a "conscious decision to limit educator access to the platform" (UB-LD-01) in order to ensure materials met pedagogic, copyright and branding requirements. This represented a decision to configure technology to address a social and organisational challenge, rather than any technical need. The decision was in part motivated by strong representations from the legal department, insisting that some way to standardise or control the development process be found. Educators at University C, who enjoyed the most relative freedom in the development process, were still subject to learning designers" "final say" (UCLD-01) over the acceptability of materials . This final say was at times exercised where learning designers "said no" (UC-LD-01) to certain materials during development waystages if they were deemed to fall short of the required standards.

Perhaps surprisingly, interview data revealed a fairly limited degree of educator resistance to this unbundling, once learning designers had established their central position and collaborative working relationships in MOOC development. As MOOC projects developed, educators became aware of the level of resource, time and expertise required to produce the courses. They also had to manage their existing workloads, and so were relatively happy to relinquish responsibility to learning designers and other parties (such as media producers). Indeed, educators built up a level of trust in learning designers to "manage the projects" (UC-LD-03), as they were seen to "know what they are doing" (UB-ED-06), especially with regard to working with high-quality video production. Learning designers in turn were keen to offer to manage the complexity for educators, at times offering a kind of "service" in which they could "just take all the crap off them" (UA-LD-01). It was perhaps also significant that no clear link existed between MOOCs and formal measures of academic performance, thus reducing the "stakes" over the control of projects.

\section{Discussion}

\section{MOOCs as driver of distinctive unbundling}

In evidencing the unbundling of educator roles, this study contributes observational evidence of the phenomenon in an area of research where empirical work is frequently lacking (Gehrke \& Kezar, 2015, p. 95). In the case studies, the massive and open features of MOOCs link clearly to the institutions' desire for reputational enhancement (confirming León-Urritia et al., 2018) and lead to particular tensions and 
constraints in MOOC development. Czerniewicz et al. (2016) have shown that particular tensions and constraints emerge in MOOC development. This study found that responses to these tensions and constraints in an educational context in which MOOCs do not neatly fit led to an extensive unbundling of conventional educator roles in terms of Boyer's teaching and integration functions.

The findings of this study elaborate on educator views reported in Zheng et al. that teaching on MOOCs is "totally different from teaching regular college classes" (2016, p. 216). By giving attention to learning designers and others with roles in MOOC development across multiple sites, this research builds on educator-focussed studies of MOOCs such as Najafi et al. (2015) and Blackmon (2018). Studies of learning designer roles in conventional online learning contexts have described collaborative "bridging" (Cowie \& Nichols, 2010, p. 77) and "broker" (Keppell, 2007, p. 68) roles. However, this study goes further in identifying learning designers as a fulcrum or linchpin in MOOC projects and argues that MOOC development and the unbundling of educator roles in complex and demanding contexts cannot be fully understood without considering learning designers.

\section{Learning designers as central in MOOC development}

Zheng et al. (2016) reported that educators face challenges of "vague guidelines", "invisible systems and actors" and "conflicts" in MOOC projects, which need some kind of "project manager" (p. 217). By including the learning designer perspective (and their links to others involved in MOOCs), this study illuminates such seemingly invisible roles and systems and resonates with earlier studies of learning technologists in online learning. Such related studies include Beetham et al.'s (2001) identification of "multi-skilled and peripatetic" individuals with a "pivotal role" in learning technology projects (p. 4). Similarly, Oliver (2002) highlighted individuals with "hidden negotiation" skills, occupying roles which are "hybrid, marginal, yet central to institutional processes and change" (p. 246). Interestingly, Whitchurch's (2013, p. 3) insights into "third space professionals" in British, Australian and North American contexts who work across boundaries of roles and departments in HE echo these characteristics, as reported in White et al. (2020). This idea of third space has been applied to "educational designers" (Bisset, 2018, p. 1) who exploit "collaborative expertise" and "strategic agency" (Bisset, 2018, p. 16) in Australian digital education projects in HE. Whitchurch's work does not directly intersect with that of Beetham et al. (2001) or Oliver (2002), despite both referencing Gornall's (1999) concept of "new specialists" (p. 4) in UK HE. Across cases in this study, however, it is clear that MOOC learning designers span boundaries of legal, marketing, media production and educational functions in universities (see White et al., 2020, for more on MOOCs and learning designers in the third space in HE). Such activities clearly meet Paulson's (2002) definition of unbundling in dividing educators' teaching and integration roles into specialist functions, as the findings have shown.

An unbundling of educator roles in the production of course content was particularly clear in the findings, and was linked to issues of media production values, branding and copyright of materials used. Learning designers did not directly take on the content expert aspect of teacher roles, but certainly exercised more control over course production processes and decisions. The need for particular expertise in video production and the workload demands associated with it have been identified in conventional online learning contexts (Gregory \& Lodge, 2015). However, this study has shown how conventional "broker" (Cowie \& Nichols, 2010, p. 77) or "bridging" (Keppell, 2007, p. 68) roles of learning designers are extended to a more central function in course designs which depend heavily on video. This leads to a more extensive unbundling of educator roles in MOOCs than that described in studies of non-MOOC online courses, such as that by Tucker and Neely (2010).

Constraints on educator materials development roles were also linked to concerns with maintaining copyright standards. Such concerns are intensified in open large-scale courses and have previously been identified by Czerniewicz et al. (2016) in looking at a single MOOC and institution. This study confirms Czerniewicz et al.'s insights and further illustrates the various ways in which MOOC development processes are adapted to accommodate control of content (through development processes, configuration of technology, learning designer roles) across a range of MOOCs and institutions. The study also provides empirical evidence of these copyright issues, adding to the reviews and commentary in Cheverie (2013) and Literat (2015). 


\section{Conclusion}

The subject of unbundling of roles in HE, especially in online learning, has been the subject of much commentary and a limited amount of research. Using Boyer's (1990) categorisations of scholarship, this study has investigated the extent to which educator roles are unbundled in the distinctive context of MOOC development. Using a multi-site case study of three UK universities, the study found that MOOC development represents a distinctive context for the unbundling of educator roles in terms of Boyer's categories of teaching and integration (collaboration on and development of courses and learning materials). Though based on in-depth data collection, the cases inevitably give a limited portrayal of MOOC development at universities working with a particular platform provider in the UK and may not be generalisable to other platform providers or international contexts. Further studies might investigate unbundling in such contexts.

The underlying concern with reputational enhancement and converse sense of reputational risk that accompanies high-profile massive and open courses was found to influence this unbundling process. In the cases, MOOC development involves collaboration with a quasi-commercial partner in which educator roles are unbundled to a range of other functions both internal and external to institutions, including media production, legal and marking departments and platform providers. As a result, learning designers become increasingly central in shaping and making decisions on course design, course content and development procedures. The findings contribute empirical evidence of the unbundling processes in online learning and inform understandings of the ways in which educators and learning designers collaborate in MOOC development projects. Understanding this unbundling process can help those involved in the recruitment or training for online projects or those undertaking planning and decision-making for such projects.

\section{Acknowledgements}

Some of the research on which this work was based was funded by the UK Engineering and Physical Sciences Research Council, Grant Number: EP/G036926/1.

\section{Conflict of interests}

The authors are or have been employed at universities that are members of the MOOC consortium from which the case studies are drawn.

\section{References}

Beetham, H., Jones, S., \& Gornall, L. (2001). Career development of learning technology staff: Scoping study final report. JISC.

https://www.webarchive.org.uk/wayback/archive/20090429090334/http://www.jisc.ac.uk/publications /publications/cdssfinalreport.aspx

Bennett, S., \& Oliver, M. (2011). Talking back to theory: The missed opportunities in learning technology research. Research in Learning Technology, 19(3), 179-189. https://doi.org/10.3402/rlt.v19i3.17108

Bisset, D. (2018). Role of educational designers in higher education institutions. In F. Padró, C. Bossu, \& N. Brown (Eds.), Professional and support staff in higher education (pp. 1-20). Springer. https://doi.org/10.1007/978-981-10-1607-3 14-1

Blackmon, S. (2018). MOOC makers: Professors' experiences with developing and delivering MOOCs. International Review of Research in Open and Distributed Learning, 19(4). https://doi.org/10.19173/irrodl.v19i4.3718

Boshier, R. (2009). Why is the scholarship of teaching and learning such a hard sell? Higher Education Research \& Development, 28(1), 1-15. https://doi.org/10.1080/07294360802444321

Bowen, G. (2009). Document analysis as a qualitative research method. Qualitative Research Journal, 9(2), 27-40. https://doi.org/10.3316/QRJ0902027

Boyer, E. (1990). Scholarship reconsidered: Priorities of the professoriate. Jossey-Bass.

Boyer, E. L., Braxton, J. M., Ream, T. C., \& Moser, D. (2015). Scholarship reconsidered : Priorities of the professoriate, expanded edition. Jossey-Bass. 
Braun, V., \& Clarke, V. (2006). Using thematic analysis in psychology. Qualitative Research in Psychology, 3(2), 77-101. https://doi.org/10.1191/1478088706qp063oa

Bulfin, S., Pangrazio, L., \& Selwyn, N. (2014). Making 'MOOCs': The construction of a new digital higher education within news media discourse. The International Review of Research in Open and Distance Learning, 15(5). https://doi.org/10.19173/irrodl.v15i5.1856

Caplan, D., \& Graham, R. (2008). The development of online courses. In T. Anderson (Ed.), Theory and practice of online learning (2nd ed., pp. 245-264). AU Press.

Cheverie, J. (2013, July 19). Copyright challenges in a MOOC environment. Educause. https://library.educause.edu/resources/2013/7/copyright-challenges-in-a-mooc-environment

Cowie, P., \& Nichols, M. (2010). The clash of cultures: Hybrid learning course development as management of tension. International Journal of E-learning and Distance Education, 24(1), 77-90. http://www.ijede.ca/index.php/jde/article/view/607

Creswell, J. (2014). Research design: Qualitative, quantitative, and mixed methods approaches (4th ed.). Sage.

Czerniewicz, L., Glover, M., Deacon, A., \& Walji, S. (2016). MOOCs, openness and changing educator practices: An activity theory case study. In S. Cranmer, N. B. Dohn, M. de Laat, T. Ryberg, \& J. A. Sime (Eds.), Proceedings of the 10th International Conference on Networked Learning 2016 (pp. 287-294). Lancaster University. http://137.158.155.94/handle/11427/19714

Daniel, J. (2014). Foreword to the special section on massive open online courses. MERLOT Journal of Online Learning and Teaching, 10(1), i-iv. https://jolt.merlot.org/vol10no1/daniel_foreword_0314.pdf

Elton, L. (1996). Task differentiation in universities: Towards a new collegiality. Tertiary Education and Management, 2(2), 138-145. https://doi.org/10.1080/13583883.1996.9966894

Gehrke, S., \& Kezar, A. (2015). Unbundling the faculty role in higher education: Utilizing historical, theoretical, and empirical frameworks to inform future research. In M. B. Paulson (Ed.), Higher education: Handbook of theory and research (pp. 93-150). Springer. https://doi.org/10.1007/978-3$\underline{319-12835-13}$

Gornall, L. (1999). "New professionals": Change and occupational roles in higher education. Perspectives: Policy and Practice in Higher Education, 3(2), 44-49. https://doi.org/10.1080/13603109981847

Gregory, M., \& Lodge, J. (2015). Academic workload: the silent barrier to the implementation of technology-enhanced learning strategies in higher education. Distance Education, 36(2), 210-230. https://doi.org/10.1080/01587919.2015.1055056

Kenny, R., Zhang, Z., \& Schwier, R. (2005). A review of what instructional designers do: Questions answered and questions not asked. Canadian Journal of Learning and Technology, 31(1). https://doi.org/10.21432/T2JW2P

Keppell, M. J. (2007). Instructional designers on the borderline: Brokering across communities of practice. In M. J. Keppell (Ed.), Instructional design: Case studies in communities of practice (pp. 68-90). IGI Global. https://doi.org/10.4018/978-1-59904-322-7

Kirkwood, A., \& Price, L. (2014). Technology-enhanced learning and teaching in higher education: What is 'enhanced'and how do we know? A critical literature review. Learning, Media and Technology, 39(1), 6-36. https://doi.org/10.1080/17439884.2013.770404

León-Urritia, M., Cobos, R., \& Dickens, K. (2018). MOOCs and their influence on higher education institutions: Perspectives from the insiders. Journal of New Approaches in Educational Research, 7(1), 40-45. https://doi.org/10.7821/naer.2018.1.252

Literat, I. (2015). Implications of massive open online courses for higher education: mitigating or reifying educational inequities? Higher Education Research \& Development, 34(6), 1164-1177. https://doi.org/10.1080/07294360.2015.1024624

Littlejohn, A. (2013). Understanding massive open online courses. CEMCA EdTech Notes. http://cemca.org.in/ckfinder/userfiles/files/EdTech Notes 2_Littlejohn_final_1June2013.pdf

Liyanagunawardena, T. R., Adams, A. A., \& Ann Williams, S. (2013). MOOCs: A systematic study of the published literature 2008-2012. The International Review of Research in Open and Distance Learning, 14(3), 202-227. https://doi.org/10.19173/irrodl.v14i3.1455

Lowenthal, P., Snelson, P., \& Perkins, C. (2018). Teaching massive, open, online, courses (MOOCs): Tales from the front line. International Review of Research in Open and Distributed Learning, 19(3). https://doi.org/10.19173/irrodl.v19i3.3505 
Macfarlane, B. (2011). The morphing of academic practice: Unbundling and the rise of the paraacademic. Higher Education Quarterly, 65(1), 59-73. https://doi.org/10.1111/j.14682273.2010.00467.x

Moore, M. G. (2007). Teamwork. American Journal of Distance Education, 21(3), 113-116. https://doi.org/10.1080/08923640701341646

Najafi, H., Rolheiser, C., Harrison, L., \& Håklev, S. (2015). University of Toronto instructors' experiences with developing MOOCs. The International Review of Research in Open and Distributed Learning, 16(3). https://doi.org/10.19173/irrodl.v16i3.2073

Nibert, M. (2001). Boyer's model of scholarship. Pacific Crest Faculty Development Series: Expectations of Faculty in Higher Education. http://www.facultyguidebook.com/BoyerModel.pdf

Oliver, M. (2002). What do learning technologists do? Innovations in Education and Training International, 39(4), 245-252. https://doi.org/10.1080/13558000210161089

Paulson, K. (2002). Reconfiguring faculty roles for virtual settings. The Journal of Higher Education, 73(1), 123-140. https://doi.org/10.1080/00221546.2002.11777133

Rodriguez, O. (2013). The concept of openness behind c and X-MOOCs (Massive Open Online Courses). Open Praxis, 5(1), 67-73. https://www.learntechlib.org/p/130655/

Sandelowski, M. (2010). What's in a name? Qualitative description revisited. Research in Nursing \& Health, 33, 77-84. https://doi.org/10.1002/nur.20362

Selwyn, N. (2010). Looking beyond learning: Notes towards the critical study of educational technology. Journal of Computer Assisted Learning, 26(1), 65-73. https://doi.org/10.1111/j.13652729.2009.00338.x

Selwyn, N. (2017). Education and technology. Key issues and debates (2nd ed.). Bloomsbury.

Simons, H. (2009). Case study research in practice. Sage. https://doi.org/10.4135/9781446268322

Stake, R. (2008). Qualitative case studies. In N. Denzin \& Y. Lincoln (Eds.) Strategies of qualitative inquiry (pp. 119-149). Sage.

Stake, R. (2013). Multiple case study analysis. Guildford Press.

Suri, H. (2011). Purposeful sampling in qualitative research synthesis. Qualitative Research Journal, 11(2), 63-75. https://doi.org/10.3316/QRJ1102063

Tucker, J., \& Neely, P. (2010). Unbundling faculty roles in online distance education programs. The International Review of Research in Open and Distributed Learning, 11(2). https://doi.org/10.19173/irrodl.v11i2.798

Veletsianos, G., \& Shepherdson, P. (2016). A systematic analysis and synthesis of the empirical MOOC literature published in 2013-2015. The International Review of Research in Open and Distributed Learning, 17(2). https://doi.org/10.19173/irrodl.v17i2.2448

Weller, M. (2011). The digital scholar: How technology is transforming scholarly practice. Bloomsbury. https://doi.org/10.5040/9781849666275

Weller, M. (2015). MOOCs and the Silicon Valley narrative. Journal of Interactive Media in Education, 1. https://doi.org/10.5334/jime.am

Whitchurch, C. (2013). Reconstructing identities in higher education: The rise of "third space" professionals. Routledge. https://doi.org/10.4324/9780203098301

White, S. T. (2019). Learning designers and educators in the "third space": The socio-technical construction of MOOCs in UK higher education [Doctoral dissertation, University of Southampton]. ePrints. https://eprints.soton.ac.uk/433536/

White, S., \& White, S. (2016). Learning designers in the 'third space': The socio-technical construction of MOOCs and their relationship to educator and learning designer roles in HE. Journal of Interactive Media in Education, 1(17), 17-29. https://doi.org/10.5334/jime.429

White, S., White, S., \& Borthwick, K. (2020). Blended professionals, technology and online learning: Identifying a socio-technical third space in higher education. Higher Education Quarterly. https://doi.org/10.1111/hequ.12252

Zheng, S., Wisniewski, P., Rosson, M. B., \& Carroll, J. M. (2016). Ask the instructors: Motivations and challenges of teaching massive open online courses. Proceedings of the 19th ACM Conference on Computer-Supported Cooperative Work \& Social Computing (pp. 205-220). ACM. https://doi.org/10.1145/2818048.2820082 
Corresponding author: Steven White, swhite $@$ aub.ac.uk

Copyright: Articles published in the Australasian Journal of Educational Technology (AJET) are available under Creative Commons Attribution Non-Commercial No Derivatives Licence (CC BY-NC-ND 4.0). Authors retain copyright in their work and grant AJET right of first publication under CC BY-NC-ND 4.0 .

Please cite as: White, S., White, S., \& Borthwick, K. (2020). MOOCs, learning designers and the unbundling of educator roles in higher education. Australasian Journal of Educational Technology, 36(5), 71-84. https://doi.org/10.14742/ajet.6111 